\title{
Morphological and molecular diagnosis of diseases of free-ranging crab-eating foxes (Cerdocyon thous)
}

\author{
[Diagnóstico morfológico e molecular de doenças de cachorro-do-mato \\ (Cerdocyon thous) de vida livre \\ G.J.S. Uzai ${ }^{1}$, C.P. Monteiro ${ }^{1}$, R. Soares ${ }^{1}$, M.A. Silva ${ }^{1}$, A.R. Oliveira ${ }^{2}$, \\ D.O. Santos ${ }^{2}$, R.L. Santos ${ }^{2}$, L.C. Nunes ${ }^{1 *}$ \\ ${ }^{1}$ Universidade Federal do Espírito Santo - Vitória, ES \\ ${ }^{2}$ Escola de Veterinária - Universidade Federal de Minas Gerais - Belo Horizonte, MG
}

\begin{abstract}
The aim of this study was to investigate the occurrence of diseases in free-ranging wild canids that were roadkill on highways in the State of Espírito Santo, Brazil. PCR tests were performed for the detection of Brucella sp., Babesia sp., Rangelia sp., and Hepatozoon sp. in the spleen. Morphological evaluation and identification of parasites was performed in the liver and lung. Twenty specimens of $C$. thous were necropsied at the Animal Pathology Sector of the Veterinary Hospital of the Universidade Federal do Espírito Santo. Tissue samples were processed for histopathological examination and polymerase chain reaction (PCR) analysis. There was no PCR amplification of genomic DNA sequences of Brucella sp., Babesia sp., Rangelia sp., and Hepatozoon sp. using DNA extracted from the spleen as template. Histologically, lesions associated with parasitism by Platynosomum sp. and Angiostrongylus sp. were observed in the liver and lung, respectively. This is the first report of Platynosomum sp. and Angiostrongylus sp. parasitism in C. thous in the state of Espírito Santo, Brazil. Therefore, this study demonstrated parasitism of crab-eating foxes by Platynosomum sp. and Angiostrongylus sp. Importantly, no evidence of infection with Brucella sp., Babesia sp., Rangelia sp., and Hepatozoon sp. was obtained by PCR analysis.
\end{abstract}

Keywords: wild canid, Histopathology, PCR

\section{RESUMO}

O objetivo deste estudo foi investigar a ocorrência de doenças em canídeos silvestres de vida livre que foram atropelados em rodovias no estado do Espírito Santo, Brasil. Testes de PCR foram realizados para a deteç̧ão de Brucella $s p$., Babesia sp., Rangelia sp. e Hepatozoon $s p$. no baço. A avaliação morfológica e a identificação de parasitas foram realizadaa no fígado e no pulmão. Vinte espécimes de C. thous foram necropsiados no Setor de Patologia Animal do Hospital Veterinário da Universidade Federal do Espírito Santo. Amostras de tecido foram processadas para exame histopatológico e análise de reação em cadeia da polimerase (PCR). Não houve amplificação por PCR das sequências de DNA genômico de Brucella sp., Babesia sp., Rangelia sp. e Hepatozoon sp. usando-se DNA extraído do baço como modelo. Histologicamente, lesões associadas ao parasitismo por Platynosomum sp. e Angiostrongylus sp. foram observadas no fígado e no pulmão, respectivamente. Este é o primeiro relato de Platynosomum sp. $e$ Angiostrongylus sp. parasitismo em C. thous no estado do Espírito Santo, Brasil. Portanto, este estudo demonstrou parasitismo de cachorro-do-mato por Platynosomum $s p$. e Angiostrongylus $s p$. É importante detacar que não há evidências de infecção por Brucella sp., Babesia sp., Rangelia sp. e Hepatozoon sp. por análise de PCR.

Palavras-chave: canídeo silvestre, histopatologia, PCR

Recebido em 28 de janeiro de 2021

Aceito em 9 de fevereiro de 2021

*Autor para correspondência (corresponding author)

E-mail: louisianecn@gmail.com 


\section{INTRODUCTION}

Some of the diseases that affect wild animals may also affect human or domestic animal populations. Therefore, the diagnosis and study of these diseases may provide valuable knowledge on circulation of diseases among domestic and wild animals. The zoonoses with a wildlife reservoir constitute a public health issue worldwide. The importance of these diseases has been recognized, demanding attention to obtain data on natural occurrence of diseases and assessment of risk factors in certain ecosystems (Almeida et al., 2018). The crab-eating fox (Cerdocyon thous) is a wild canid that, in addition to its natural broad feeding behavior, also have carcasses of domestic animals, processed foods, and human-generated food waste as food sources.

This situation favors the occurrence of infectious diseases that may affect domestic dogs since $C$. thous often lives near human habitats. This species has been suffering from loss of habitat, hunting, and trampling. They are considered one of the wild mammal species that suffer the most from the impact of roads and motor vehicles in the Brazilian territory (Beisigel et al., 2013). Considering the scarcity of information on diseases affecting the crab-eating fox, the aim of this study was to investigate the occurrence of diseases in free-ranging crab-eating foxes that were road-killed on highways in the State of Espírito Santo, Brazil.

\section{MATERIAL AND METHODS}

Twenty free-ranging crab-eating foxes (Cerdocyon thous) that were road killed between January and July 2018 and obtained from the Reserva Biológica de Sooretama (Sooretama, State of Espírito Santo, Brazil), Museu de Biologia Professor Mello Leitão (Santa Tereza, State of Espírito Santo, Brazil), Universidade Federal do Norte Fluminense Darcy Ribeiro (UENF; Campos dos Goytacazes, State of Rio de Janeiro, Brazil), and the Secretaria do Meio Ambiente de Marataízes (Marataízes, State of Espírito Santo, Brazil), were included in this study. This experimental protocol has been approved by the Ethics Committee on Animal Use of Universidade Federal do Espírito Santo (UFES) under protocol number 065/2017. All carcasses were kept frozen at the place of origin and sent to the Laboratório de Patologia Animal do Hospital Veterinário da UFES, where they were subjected to necropsy.

Samples of the spleen, liver, and lungs $(1 \mathrm{~cm} \times 1$ $\mathrm{cm}$ in duplicates) were stored at $-80^{\circ} \mathrm{C}$. Tissue samples were also fixed in $10 \%$ buffered formalin solution for histological processing, and $3 \mu \mathrm{m}$ sections were stained with hematoxylin and eosin (HE). Liver and lung samples containing helminth-associated lesions were photo documented using a Dino Eye capture camera, and the slides containing parasites were selected. Then, the length and width of all the eggs and fragments of adult parasites were measured using the ImageJ 64- bit Java 1.8.0_112 software and the mean value was obtained.

Frozen tissue samples were processed at the Laboratório de Patologia Molecular at the Universidade Federal de Minas Gerais (Belo Horizonte, State of Minas Gerais, Brazil) for DNA extraction according to the guanidine extraction protocol (Pitcher et al., 1989). PCR for brucellosis was conducted as previously described by Bayliet et al. (1992), and PCR for hemoparasites (Babesia sp. Rangelia sp. and Hepatozoon sp.) was performed according to the protocol described by Harrus et al. (2011). PCR was performed using template DNA samples from 19 out of the 20 animals because samples from one animal had advanced degree of autolysis. Positive control for Brucella sp. was a previously confirmed case affecting the canine placenta, and positive control for piroplasmida was a confirmed case of Theileria equi in equine liver.

\section{RESULTS}

Sixty per cent of the animals (12/20) originated from the Reserva Biológica de Sooretama $\left(19^{\circ} 03^{\prime} 14.3^{\prime \prime} \mathrm{S} 40^{\circ} 05^{\prime} 48.0^{\prime \prime} \mathrm{W}\right), 30 \%$ (6/20) from the Museu de Biologia Professor Mello Leitão

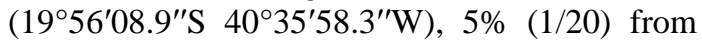
the Universidade Estadual do Norte Fluminense Darcy Ribeiro $\left(21^{\circ} 45^{\prime} 49.0^{\prime \prime} \mathrm{S} 41^{\circ} 17^{\prime} 15.1^{\prime \prime} \mathrm{W}\right)$, and $5 \%(1 / 20)$ from the Secretaria de Meio Ambiente de Marataízes $\left(21^{\circ} 02^{\prime} 23.8^{\prime \prime} \mathrm{S} \quad 40^{\circ} 49^{\prime} 18.2^{\prime \prime} \mathrm{W}\right)$. Considering their sex, $70 \%$ (14/20) were males and $30 \%(6 / 20)$ females, whereas $95 \%$ (19/20) were adults, and 5\% (1/20) juveniles.

One animal had evidence of traumatic lesions, including fractures that were inflicted by an attack from a domestic dog. PCR for Brucella sp., 
Babesia sp., Rangelia sp., and Hepatozoon sp. had negative results for all spleen samples. Microscopic evaluation of the liver revealed that $75 \%$ of the animals (15/20) had hepatic congestion, $65 \%(13 / 20)$ periductal fibrosis, $15 \%$ $(3 / 20)$ biliary ductal proliferation, 5\% (1/20) periductal hyperplasia and 5\% (1/20) lymphocytic inflammatory infiltrate. In $30 \%(6 / 20)$ of the animals, helminths with morphologic features of trematodes were observed in the lumen of bile ducts. Many trematodes with an oral sucker and eggs with a yellow to brown shell were observed within the organism (Gardiner and Poynton, 2006). Cross-sections of the parasites demonstrated an average length of $204.03 \mu \mathrm{m}$ and average width of $166.27 \mu \mathrm{m}$ of suckers. In addition, $17 \mathrm{egg}$ fragments (measuring on average $32.64 \pm 1.32 \mu \mathrm{m}$ length and $18.73 \pm 1.95 \mu \mathrm{m}$ width) with thick brown shell were observed with miracidia in the interior (Figure 1).

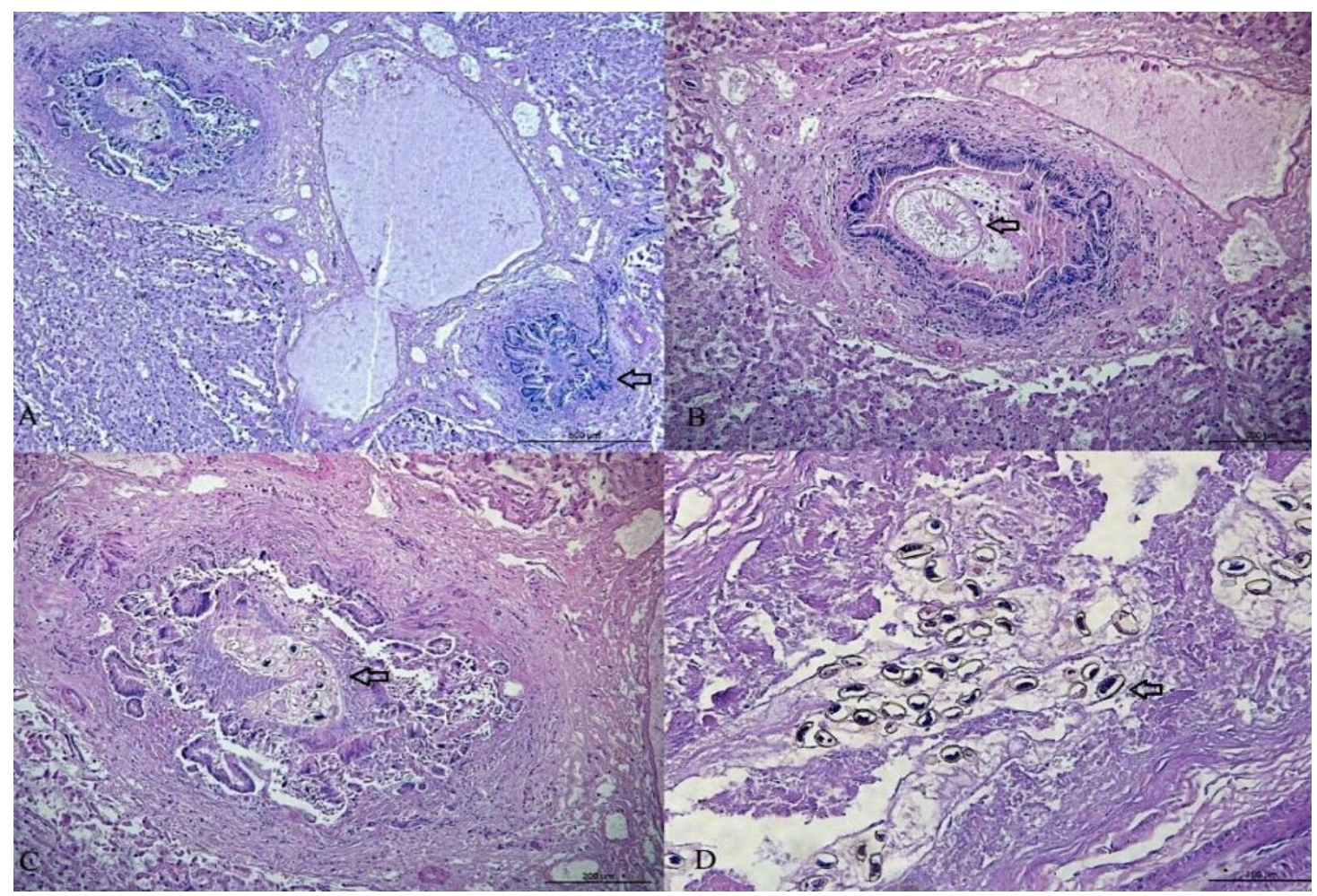

Figure 1. Adult male crab-eating-fox (Cerdocyon thous), liver: A) Periductal fibrosis, ductal proliferation, ductal hyperplasia (arrow), and an adult trematode within the bile duct (bar $=500 \mu \mathrm{m}$ ); B) Parasite sucker within the bile duct (arrow) with mild periductal lymphocytic inflammatory infiltrate (bar $=200 \mu \mathrm{m})$; C) Periductal fibrosis, proliferation of ducts $(*)$, and parasites with eggs (arrow) within the bile duct (bar = $200 \mu \mathrm{m})$; D) Fragments eggs of parasites with thick brown in the parenchyma (bar $=100 \mu \mathrm{m})$. Hematoxylin and eosin staining.

Microscopic evaluation of the lung revealed that $100 \%(20 / 20)$ of the animals had congestion, $95 \%$ (19/20) edema, 55\% (11/10) hemorrhage, 15\% $(3 / 20)$ diffuse interstitial histiocytic inflammatory infiltrate, $5 \%(1 / 20)$ severe multifocal granulomatous pneumonia, and 5\% (1/20) severe diffuse hemosiderosis. One animal (1/20) had nematode larvae within pulmonary alveoli. Sections of these parasites demonstrated elongated, spiral-shaped larvae, totaling six parasites, measuring on average 176.21 $\pm 9.14 \mu \mathrm{m}$ in length and $14.24 \pm 1.37 \mu \mathrm{m}$ width. The larvae were surrounded by a severe granulomatous inflammatory reaction with numerous macrophages, multinucleated giant Langhans cells, and marked diffuse hemosiderosis (Figure 2). Neither adult parasites nor egg were observed.

\section{DISCUSSION}

The occurrence and reports of hepatic and pulmonary parasites in wild canids are extremely rare, and this is the first record of Platynosomum sp. and Angiostrongylus sp. in C. thous in the state 
of Espírito Santo, Brazil. Infections with these parasites have been found in domestic dogs and cats, but in wild canids (especially crab-eating fox), there are just a few reports in Minas Gerais, Brazil. In this study, morphological features of the hepatic helminths allowed identification as trematodes. The most common trematodes in wild canids belong to the family Dicrocoeliidae, including Platynosomum sp. and Athesmia heterolecithodes (Duarte, 2007).

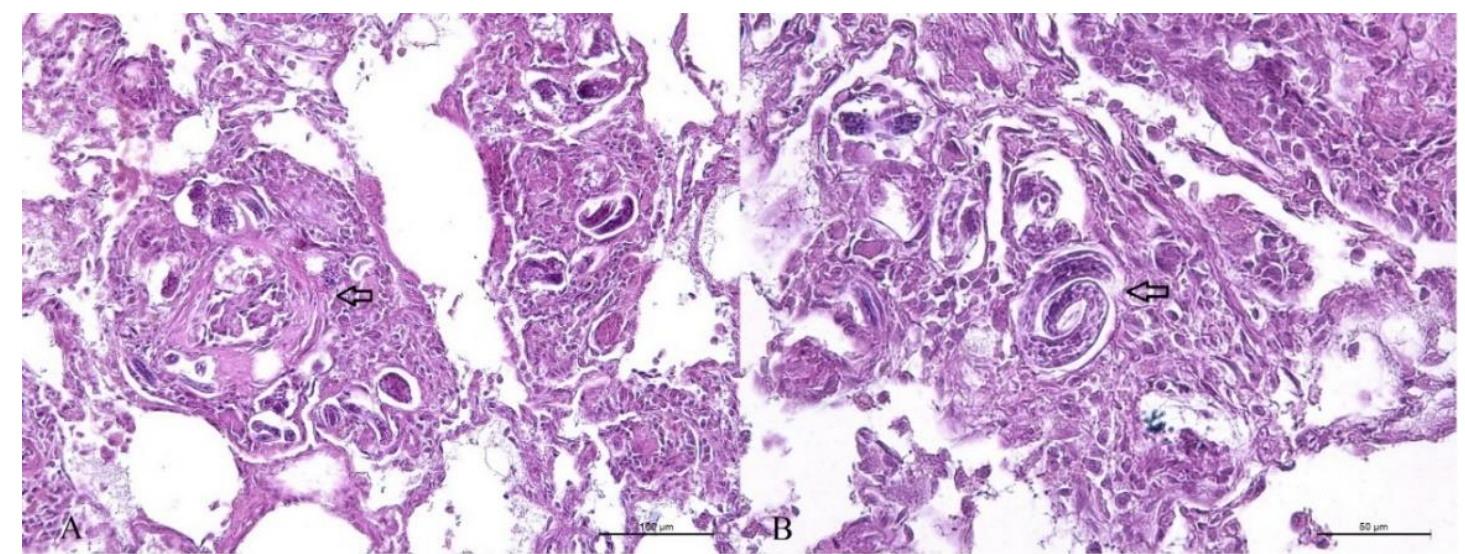

Figure 2. Adult male crab-eating-fox (Cerdocyon thous), lung: A) Granulomatous pneumonia (arrow) with intralesional nematode larvae (bar $=100 \mu \mathrm{m})$; B) Lung with elongated and spiral nematode larvae $($ bar $=$ $50 \mu \mathrm{m})$. Hematoxylin and eosin staining.

According to Duarte (2007) there are few and subtle differences between Platynosomum and Athesmia, such as the more elongated and larger body and the intraceacal ventral sucker of Athesmia. However, the absence of fresh adult parasites for morphometric analysis makes this differentiation difficult. Therefore, epidemiological aspects should be considered. There are no reports of $A$. heterolecithodes in Espírito Santo, Brazil, but Platynosomum sp. has already been report in domestic cats (Gava et al., 2015; Campos et al., 2018). In addition, there are reports of infection of canids with Platynosomum sp., as described by Duarte (2007), in Juiz de Fora, MG, Brazil. Curi (2010) eggs of Platynosomum sp. in C. thous and in Chrysocyon brachyurus (maned wolf), by fecal examination in the region of Serra do Cipó - MG, Brazil.

Hepatic lesions observed in this study, including periductal fibrosis, periductal hyperplasia, ductal proliferation, presence of eggs, and intraductal adult parasites, were compatible with biliary parasitic diseases, such as Platynosomum sp. in cats (Ramos et al., 2017) and lesions caused by Fasciola hepatica and Capillaria hepatica. However, the histological characteristics of these two last parasites are quite different (Duarte, 2007). In relation to the pulmonary lesions found in the animals of this study, the most evident changes such as congestion, edema, and hemorrhage may also be associated with traumas resulting from running over. However, one of the cases had a multifocal granulomatous pneumonia associated with parasite larvae. Ferreira Júnior et al. (2017) found that multifocal to coalescing granulomatous arteritis in $C$. thous was associated with the presence of parasites measuring 100-200 $\mu \mathrm{m}$ that were identified as Angiostrongylus vasorum. In this study, lavae found in the lung had sizes compatible with the findings of Ferreira Júnior et al. (2017) and therefore it was morphologically compatible with A. vasorum.

In the Brazilian territory, Angiostrongylus sp. had been described in $C$. thous in the state of Paraná (Duarte, 2007). In São Paulo, Angiostrongylus sp. was diagnosed by histopathology (Ferreira Júnior et al., 2017). These studies further support the interpretation that Angiostrongylus sp. was the pulmonary parasite identified in this study. Oliveira-Filho et al. (2012) also had negative results when searching for Brucella sp. in the crab-eating foxes. In contrast, Dorneles et al. (2014) diagnosed the B. abortus infection in five C. thous, while Hayashi (2013) performed PCR in 41 crab-eating foxes from Parque Nacional da Emas region, Brazil, but did not find any positive sample for Brucella sp. These negative results for Brucella sp. in crab-eating foxes, including those in the present study, despite using molecular tests that are highly sensitive and specific, indicates a 
low frequency of Brucella sp. infection in wild canid populations. However, the general eating habit of the crab-eating fox, which can sometimes feed on aborted fetuses, placental tissues, and farm animal carcasses, indicates a potential role of the crab-eating foxes in the transmission of brucellosis, which needs to be better clarified.

Babesia sp., Rangelia sp., and Hepatozoon sp. are commonly detected in domestic animals of different species in several regions of Brazil, using various diagnostic techniques. However, in this study, DNA sequences of these pathogens were not detected. However, in a study in the Brazilian Pantanal, 78 C. thous were tested for Babesia sp. by ELISA and PCR techniques with 42 seroreactive but only one animal that was PCR positive (Sousa et al., 2018). Conversely, in the highway ES-060 between the municipalities of Guarapari and Vila Velha, Almeida et al. (2013) diagnosed Babesia sp. in 10 of the 58 C. thous tested by PCR. The same authors used animal samples from regions similar to the present study and found a prevalence of $17.24 \%$. However, the same authors revealed that in the sampled period (2004-2009), all positive animals showed concomitant infestation by ticks. In the present study, in addition to having collected material in later years, none of the animals had ectoparasites, which may explain the negative results for Babesia sp.

When rangeliosis is considered, the results obtained in the present study are similar to those of Almeida et al. (2013) and Sousa et al. (2018), who also used PCR in their studies, in which even animals with ticks were negative for Rangelia sp. In contrast, Rangelia sp. was diagnosed in crabeating foxes by PCR in São Paulo and Rio Grande do Sul, including free-ranging and captive animals. In that particular study, 13 were freeranging, and $46.2 \%$ were positive (Soares et al., 2014). In the same region, the Rangelia vitalii was diagnosed by PCR in one out of two animals (Fredo et al., 2015). The high prevalence of rangeliosis observed in the states of São Paulo and Rio Grande do Sul can be explained by the fact that those are endemic regions for this hemoparasite (Soares et al., 2014).

Hepatozoonosis is a relatively common disease with a high prevalence in crab-eating foxes in different regions of Brazil. In the Brazilian Pantanal region, of the 78 specimens tested, $91 \%$ were positive (Sousa et al., 2018); in Espírito Santo, of the 58 animals from ES-060 between the cities of Vila Velha and Guarapari, $50 \%$ were positive (Almeida et al., 2013) and in Rio Grande do Sul, five of eight $C$. thous tested were positive for Hepatozoon sp. The absence of ectoparasites in this study can justify the negative results for Babesia sp., Rangelia sp., and Hepatozoon sp. because all these pathogens are transmitted by ticks.

\section{CONCLUSIONS}

This work represents the first reported cases of Platynosomum sp. and Angiostrongylus sp. parasitism in free-ranging $C$. thous in the State of Espírito Santo, Brazil. Importantly, there was no molecular evidence of Brucella sp., Babesia sp., Rangelia sp., or Hepatozoon sp. infection in these animals.

\section{ACKNOWLEDGMENT}

This study was financially supported by the Fundação de Amparo à Pesquisa do Espírito Santo and Coordenação de Aperfeiçoamento de Pessoal de Nível Superior. The authors acknowledge Prof. Dr. Áureo Banho dos Santos, coordinator of the project "Modelo Preditivo de Impactos sobre a Biodiversidade: Avaliação dos Impactos da Rodovia BR-101 sobre a Fauna de Vertebrados Silvestres da Rebio de Sooretama, Espírito Santo, for his kind help with the transfer of the animals.

\section{REFERENCES}

ALMEIDA, A.P.; SOUZA, T.D.; MARCILI, A.; LABRUNA, M.B. Novel Ehrlichia and Hepatozoon agents infecting the crabeating fox (Cerdocyon thous) in southeastern Brazil. J. Med. Entomol., v.50, p.640-646, 2013.

ALMEIDA, J.C.; LEAL, C.A.S.; MELO, R.P.B. et al. Co-infection by Sarcoptes scabiei and Microsporum gypseum in Free-ranging Crabeating fox, Cerdocyon thous (Linnaeus, 1766). Braz. Arch. Biol. Technol., v.61, p.1-6, 2018,

BAILY, G.G.; KRAHN, J.B.; DRASAR, B.S.; STOKER, N.G. Detection of Brucella melitensis and Brucella abortus by DNA amplification. Trop. Med. Int. Health, v.95, p.271-275, 1992. 
BEISIEGEL, B.M.; LEMOS, F.G.; AZEVEDO, F.C. et al. Avaliação do risco de extinção do cachorro-do-mato Cerdocyon thous (Linnaeus, 1766) no Brasil. Biodiv. Bras., v.3 p.160-171, 2013.

CAMPOS N.C.; SIQUEIRA, D.F.; PERIN, L.R. et al. Infecção natural por Platynosomum fastosum em felino doméstico no município de Alegre, Espírito Santo e sucesso no tratamento com praziquantel. Rev. Med. Vet., v.12, p.17-21, 2018.

CURI, N.H.A. Avaliação do estado de saúde e do risco de transmissão de doenças entre canídeos (Mammalia, Carnivora) silvestres e domésticos na região da Serra do Cipó, Minas Gerais: implicações para a conservação. 2005. 100f. Dissertação (Mestrado) - Faculdade de Veterinária, PUC, Minas Gerais.

DORNELES, E.M.S.; PELLEGRIN, A.O.; PÉRES, I.A.H.F.S. et al. Serology for brucellosis in free-ranging crab-eating foxes (Cerdocyon thous) and brown-nosed coatis (Nasua nasua) from Brazilian Pantanal. Cien. Rural, v.44, p.2193-2196, 2014.

DUARTE, H.F. Helmintofauna em Cerdocyon thous Linnaeus,1766 (Carnivora: Canidae) na região de Juiz de Fora, Minas Gerais. 2007. $70 f$. Dissertação (Mestrado) Instituto de Biologia, Universidade Federal de Juiz de Fora, MG.

FERREIRA JÚNIOR, J.A.; BLUME, G.R.; GARDINER, C. Anatomo-pathological aspects of parasitism by nematodes of the superfamily Metastrongyloidea in wild crab-eating fox (Cerdocyon thous) in Midwestern Brazil. Cienc. Rural, v.47, p.1-4, 2017.

FREDO, G.; BIANCHI, M.V.; ANDRADE, C.P. et al. Natural infection of wild canids (Cerdocyon thous and Lycalopex gymnocercus) with the intraendothelial piroplasm Rangeliavitalii in Southern Brazil. J. Wildl. Dis., v.51, p.880-884, 2015.

GARDINER, C.H.; POYNTON, S.L. An atlas of metazoan parasites in animal tissues. Washington: Armed Forces Institute of Pathology, 2006. 64p.
GAVA, M.G.; HIURA, E.; LOPES, A D.C. et al. Platynosomum fastosum in an asymptomatic cat in the state of Espírito Santo: first report. Rev. Patol. Trop., v.44, p.496-502, 2015.

HARRUS, S.; PERLMAN-AVRAHAMI, A.; MUMCUOGLU, K.Y. et al. Molecular detection of Ehrlichia canis, Anaplasma bovis, Anaplasma Platys, Candidatus Midichloria mitochondrii and Babesia canis vogeli in ticks from Israel. Clin. Microbiol. Infect., v.17, p.459-463, 2011.

HAYASHI, E.M.K. Pesquisa de cinomose, parvovirose e brucelose em carnívoros selvagens de vida livre e cães domésticos da região do Parque Nacional das Emas, Goiás. 2013. Tese (Doutorado). Universidade de São Paulo, São Paulo, SP.

OLIVEIRA-FILHO, E.F.; PINHEIRO, J.W.J.R.; SOUZA, M.M.A. et al. Serologic survery of Brucellosis in captive neotropical wild carnivores in northeast Brazil. J. Zoo Wildl. Med., v.43, p.384-386, 2012.

PITCHER, D.G.; SAUNDERS. N.A.; OWEN, R.J. Rapid extraction of bacterial genomic DNA with guanidium thiocyanate. J. Appl. Microbiol., v.8, p.151-156, 1989

RAMOS, D.G.D.S.; SANTOS, A.R.G.L.O.; FREITAS, L.D.C. et al. Feline platynosomiasis: analysis of the association of infection levels with pathological and biochemical findings. Rev. Bras. Parasitol. Vet., v.26, p.54-59, 2017.

SOARES, J.F.; DALL'AGNOL, B.; COSTA. F.B. et al. Natural infection of the wild canid, Cerdocyon thous, with the piroplasmid Rangelia vitalii in Brazil. Vet. Parasitol., v.202, p.156-163, 2014.

SOUSA, K.C.M.; FERNANDES, M.P.; HERRERA, H.M. et al. Diversity of piroplasmids among wild and domestic mammals and ectoparasites in Pantanal wetland, Brazil. Ticks Tick Borne Dis., v.9, p.245-253, 2018. 